\title{
Princípios político-pedagógicos freireanos nas políticas curriculares e no chão da escola
}

Guedes, Marilia Gabriela de Menezes

O livro Princípios político-pedagógicos freireanos nas políticas curriculares e no chão da escola ${ }^{1}$ demonstra sua singularidade e importância ao descrever em detalhes um trabalho de pesquisa que teve como objetivo compreender a contribuição de Paulo Freire na formulação de políticas e práticas curriculares nos sistemas públicos de ensino. A partir do pressuposto de que o pensamento político-pedagógico freireano está sempre em movimento, dialoga com diferentes questões contemporâneas, assim como traz elementos norteadores para a construção da teoria curricular emancipatória e eticamente comprometida com a humanização dos sujeitos. Com esse propósito, a autora organiza o livro com um texto introdutório seguido de quatro capítulos.

$\mathrm{Na}$ introdução, Guedes (2015) situa o livro como o resultado da pesquisa realizada no doutorado em educação obtido na Universidade Federal de Pernambuco e aponta como questão central discutir os fundamentos que caracterizam o pensamento freireano, de que forma eles orientam as políticas curriculares e como se materializam nas práticas pedagógicas. Apresenta argumentos que evidenciam que os fundamentos educacionais de Paulo Freire, como uma construção teórica do seu pensar crítico-dialético da realidade, estão eivados por questões que permeiam o campo do currículo, bem como consideram que toda ação educativa é sempre intencional e reflete, implícita ou explicitamente, um referencial teórico. Sendo assim, afirma ser necessário tomar o currículo como um campo investigativo, para melhor compreensão dos sistemas de ensino quanto às propostas dos gestores e à prática dos(das) professores(as).

O primeiro capítulo traz o referencial teórico em que discute o currículo na perspectiva crítica e os fundamentos político-pedagógicos de duas categorias basilares do pensamento freireano: relação e diálogo. Assim, a pesquisadora

${ }^{1}$ GUEDES, Marilia Gabriela de Menezes. Princípios político-pedagógicos freireanos nas políticas curriculares e no chão da escola. Recife: editora UFPE, 2015. 348 p. 
dialoga com diferentes autores, como, Michael Apple, Henry Giroux, Peter McLaren, Michael Young, Ivor Goodson, Eliete Santiago, Ana Maria Saul, José Augusto Pacheco, entre outros.

No segundo capítulo, a autora trata da construção metodológica, discutindo as bases teóricas que orientam a pesquisa e apresentando os procedimentos e instrumentos utilizados no caminho percorrido para a sua concretização e os elementos que fundamentaram a escolha do campo da pesquisa. Apoia-se no método materialismo histórico e dialético, utilizando a abordagem plurimetodológica. Na organização e no tratamento dos dados, recorre à Análise de Conteúdo nos termos que define Laurence Bardin.

Descreve, ainda, o estudo exploratório que permitiu conhecer os sistemas de ensino do estado de Pernambuco que apresentam traços do pensamento de Paulo Freire nas propostas educacionais e curriculares, assim como selecionar o lócus da investigação: a Secretaria de Educação do Estado de Pernambuco (SE/PE) nos anos de 1980 e 1990. Focalizando as ações desenvolvidas no segundo e terceiro governos de Miguel Arraes e, na atualidade, a Secretaria de Educação do município de Camaragibe. Nesse município, elege uma unidade escolar para acompanhar o trabalho educacional nela realizado por uma professora da Educação Infantil, a fim de compreender a contribuição de Paulo Freire para esses sistemas.

A autora analisa, no terceiro capítulo, a Secretaria de Educação do Estado de Pernambuco e aponta que esse sistema de ensino embasou as políticas de gestão, as políticas de ensino, as políticas de valorização do profissional da educação no movimento de recriação e ressignificação dos princípios freireanos, com destaque para os Fóruns Itinerantes de Educação, os Conselhos Escolares e os Círculos de Educação e Cultura. Dessa forma, esclarece que, nos processos de formulação e nas vivências das políticas e práticas curriculares no referido sistemas de ensino, estavam desenhadas as contribuições de Paulo Freire, porque defendia a participação democrática, o exercício da autonomia e a descentralização do poder como elementos basilares para a construção de uma sociedade democrática. 
A proposta educacional libertadora tomou forma com as experiências nos Círculos de Educação e Cultura reinventados criativamente pela SE/PE para os jovens e adultos pernambucanos. Nas políticas de valorização do profissional da educação, apoiadas nas discussões de Paulo Freire sobre a indissociabilidade entre teoria e prática, os referenciais freireanos foram adotados como conteúdo e forma nos processos de formação continuada dos(as) professores(as).

No quarto capítulo, ao tomar a Secretaria de Educação do município de Camaragibe, recorreu ao estudo do chão da escola para desvelar o trabalho pedagógico desenvolvido na relação docente-discente, e mostrar que o repertório de conhecimentos acerca do pensamento freireano discutido nos processos de formação estava presente no planejamento, na organização do espaço e do tempo pedagógico com as situações de produção de conhecimento. O trabalho docente revelava que educar é ato de criação, requer respeito com o ser humano e compromisso com um projeto de sociedade igualitária. A professora participante da pesquisa demonstrava, nas ações que desenvolvia, um cuidado com o trabalho que realizava à medida que as formas organizativas de espaço e tempo pedagógicos permitiam elaborar situações para a produção do conhecimento nas relações tecidas entre ela e as crianças.

Em síntese, as discussões de Paulo Freire sobre os saberes necessários para o exercício da docência na proposta educativo-libertadora norteavam as ações desenvolvidas pela professora, como a rigorosidade ética, a compreensão da natureza inconclusa do ser humano, a prática educativa como prática formadora e o processo de ensino e aprendizagem como construção criativa que permite aos(as) professores(as) e estudantes assumirem o papel de sujeitos do processo educativo.

Ao final da obra, tece algumas considerações sobre o conhecimento construído e esclarece que as questões que perpassam a pesquisa, para favorecer maior compreensão dos sistemas de ensino que reconhecem 0 pensamento freireano como fundamento na formulação de políticas e práticas curriculares, trouxeram elementos para afirmar que os princípios político- 
pedagógicos do pensamento de Paulo Freire contribuem na construção de propostas e práticas curriculares voltadas para formação humana do sujeito no processo de escolarização com base no trabalho pedagógico na relação docente-discente.

Instiga também o leitor a refletir sobre alguns desafios: ressignificar os ensinamentos freireanos, a fim de superar a realidade neoliberal, que se impõe nos dias atuais, mediante políticas que tentam falsear o processo democrático; e construir de forma inventiva e criativa mecanismos de democratização da gestão educacional que permitam concretizar um processo de formulação e vivência das políticas e práticas curriculares com a participação efetiva da sociedade nos diferentes sistemas de ensino, de modo a atender à diversidade do nosso país.

O trabalho revela sua importância por compreender que o processo educativo pode tornar-se instrumento que contribui para homens e mulheres superarem as situações desumanizadoras em que são submetidos na barbárie e nos processos de exclusão social vividas nos dias atuais. Isso é fruto do entendimento das potencialidades da educação, não como utopia irrealizável nem tampouco com consciência ingênua, mas com a consciência crítica das suas limitações e das suas possibilidades.

Essas ideias estão embasadas no pensamento político-pedagógico de Paulo Freire que revelam elementos que ajudam a entender a educação como processo de emancipação humana a serviço da transformação social e o currículo como construção de significados sociais e valores culturais. Dessa forma, o presente livro traz elementos que podem subsidiar a orientação de novos caminhos para a formulação de políticas e práticas curriculares na perspectiva crítica-emancipatória. 